\title{
Kondensacijos šilumos nuvedimo nuo tarpfazinio paviršiaus ị vandens gilumą tyrimas taikant termografinị metodą
}

\author{
Darius Laurinavičius, \\ Marijus Šeporaitis, \\ Stasys Gasiūnas \\ Lietuvos energetikos institutas, \\ Branduoliniu irrenginiu saugos laboratorija, \\ Breslaujos g. 3, LT-44403 Kaunas \\ El.paštas: Darius.Laurinavicius@lei.lt
}

Kondensacijos reiškinys yra plačiai tyrinejjamas jau daug metų. Tačiau dèl eksperimentinių duomenų fragmentiškumo bei plataus supaprastintų modelių taikymo pilnas kondensacijos reiškinio modelis nèra sukurtas. Tiek eksperimentiniai duomenys, tiek ir naudojami esami daliniai kondensacijos reiškinio modeliai yra gauti ir sukurti pirmiausia tenkinant praktinius pramonès poreikius - tyrẻjų dèmesio sulaukè tik plačiausiai naudojami režimai. Kadangi fundamentiniai tyrimai yra labai sudètingi, keliami tikslai dažniausiai apsiribojo technologinių procesų optimizavimu ir kitais praktiniais uždaviniais. Vienas tokių nepakankamai gerai ištirtų ir suprantamų režimų - stratifikuotas dvifazis tekejjimas su tiesioginès fazių sąveikos sukeliamu tarpfazinio paviršiaus nestabilumu.

Straipsnyje pateikiami vandens temperatūros profilių matavimai, kai vanduo ir besikondensuojantis garas stratifikuotai kartu teka ta pačia kryptimi. Remiantis gautais rezultatais yra aprašomas šilumos perdavimas nuo tarpfazinio (kondensacijos) paviršiaus i vandens gilumą. Matavimai buvo atlikti $x / h=9,4,14,8,20,4$ ir 39,2 $(166,312,458,932 \mathrm{~mm})$ atstumuose nuo kanalo pradžios, taikant vandens srauto netrikdantị termografini metodą. Termografinis metodas leidžia su didele skiriamąja geba ir mažu $\pm 2{ }^{\circ} \mathrm{C}$ matavimo duomenų neapibrèžtumu išmatuoti vandens temperatūrą prie pat kanalo šoninès sienelès. Skirtingos tekejjimo sąlygos buvo sukuriamos kaitaliojant ị kanalą įtekančių fazių greitị (vandens $0,014,0,028$ ir 0,056 ; o garo $6,8,10$ ir $12 \mathrm{~m} / \mathrm{s}$ ). Tiekiamo vandens temperatūra ị kanalą buvo $25^{\circ} \mathrm{C}$. Nustatyta, jog skirtinguose režimuose išmatuotų vertikalių vandens temperatūros profilių kitimas pagal aukšti nuo tarpfazinio paviršiaus iki kanalo dugno yra nevienodas ir netolygus. Tirtuoju atveju tekančio vandens sluoksnị galima suskirstyti ị 4 -ias zonas, kuriose pagal aukštị vandens temperatūra kinta skirtingai. Taip pat nustatyta, kad dèl „kondensacinio-turbulentinio sužadinimo" mechaninè garo tèkmès ittaka vandens turbulencijai pasireiškia ne tik prie pat tarpfazinio paviršiaus (iki $\sim 1 \mathrm{~mm}$ gylyje), bet ir gerokai giliau. Didinant tiekiamo garo greitị ir esant pastoviam vandens tekejimo greičiui, kondensacinis-turbulentinis sužadinimas prasideda vis arčiau tiesioginio garo ir vandens kontakto pradžios.

Raktažodžiai: dvifazis tekèjimas, vandens temperatūros profiliai, turbulencija, termografija 


\section{IVADAS}

Eksploatuojant chemijos ir energetikos pramonès objektus, daugelyje jų yra naudojamos dujinès ir skystosios takiosios terpès. Tačiau dažnai pasitaiko, kad šiluminiuose-hidrauliniuose kontūruose garavimas ir kondensacija vyksta nepageidautinose vietose arba ne taip, kaip buvo numatyta juos projektuojant. Kadangi kondensacijos intensyvumas labai priklauso nuo tekejjimo sąlygų, o jos vyksmas veikia patị tekejjimą. Šis teigiamas sąryšis lengvai sukelia ženklius vietinio slègio pokyčius, taip padidinant hidraulinių smūgių tikimybę. Be galimos neigiamos ịtakos technologinių procesų eigai, atsižvelgiant ị suteiktą garo impulsą skysčiui ir sistemų atsparumą ciklinèms smūginèms apkrovoms, iškyla reali hidraulinių smūgių grèsmè, galinčių sukelti vamzdynų trūkius. Tad labai svarbu gerai suprasti kondensacijos metu vykstančių reiškinių ryšius.

Analitinių vandens modelių gausa [1] dèl vandens ypatybių ir kondensacijos bei susijusių reiškinių kompleksinio uždavinio sudètingumo neturi vieningos sistemos. Atskirais modeliais ar koreliacijomis patenkinamo tikslumo rezultatai gaunami tik siaurų kraštinių sąlygų intervaluose (ten, kur istoriškai susiklostęs stiprus inžinerinis poreikis). Plètoti kondensacijos reiškinio teorinị modelį trukdo ne tiek eksperimentinių duomenų trūkumas, kiek jų fragmentiškumas. L. C. Ruspini [1] ir V. H. Gada [2] teigia, kad dvifazès tékmès nestabilumų reiškinys yra ribotai ištirtas. Tyrimai atliekami atskirais, labai konkrečiais dvifazio (skystis / garas) tekejjimo atvejais, esant gana griežtai apibrěžtomis kraštinèmis sąlygomis. Net ir naujausiomis CFD skaičiavimo programomis (pvz., Ansys CFX) modeliuoti stratifikuotą dvifazę tèkmę yra labai sudètinga. Siekiant sukurti korektišką universalų, pereinamuosius reiškinius apimantị, o ne su siauromis tekejimo sąlygomis susietų pusiau empirinių modelių taikymu paremtą, besikondensuojančio dvifazio tekejjimo sprendimą reikia daugiau išsamesnių ir tikslesnių tyrimų.

Pirmasis šio tyrimo tikslas - atlikti vandens temperatūros laukų matavimus stačiakampiame kanale ta pačia kryptimi stratifikuotai tekant garui su vandeniu skirtingais fazių ịtekèjimo greičių ir temperatūros deriniais. Antrasis - remiantis gautais vandens temperatūros profiliais ištirti ši- lumos nuvedimo reiškini nuo tarpfazinio (kondensacijos) paviršiaus ị vandens gilumą. Vandens temperatūros laukui matuoti pritaikytas srauto netrikdantis optinès termografijos metodas. Juo galima santykinai tiksliai (neapibrèžtumas apie $\pm 2{ }^{\circ} \mathrm{C}$ ) ir vienu metu išmatuoti vandens temperatūrą aprépiant didelį matavimo taškų skaičių ( 80 taškų $/ \mathrm{mm}^{2}$ ). Šis metodas leidžia vizualiai stebèti vandens tèkmès susidarančius nestabilumus ar turbulentinius reiškinius. S. Ghosh [3] teigia, jog vizualus tekančio srauto stebèjimas yra vienas iš šiuo metu vis dar naudojamų vandens tèkmès tyrimo būdų. Tačiau matavimo metodo skvarba i̇ vandenị apima tik ploną sluoksnį už optinio lango, t. y. gaunami temperatūros lauko dinamikos duomenys tik labai arti kanalo sienelès $(\sim 30 \mu \mathrm{m})$. Vandens temperatūros laukai išanalizuoti ir paaiškintos jų kitimo tendencijų priežastys.

\section{DARBO METODIKA}

Eksperimentiniai kondensacijos ir tarpfazinio paviršiaus nestabilumo ryšio tyrimai buvo atliekami eksperimentiniame (stačiakampiame) kanale (1 pav.), kurio ilgis $1000 \mathrm{~mm}$, vidinis plotis $20 \mathrm{~mm}$, aukštis $100 \mathrm{~mm}$. Kanalas pagamintas iš nerūdijančio plieno. Kanalo viename šone ittaisyti $4(100 \times 25 \times 2 \mathrm{~mm})$ metalo keramikos Spinel $\left(\mathrm{MgAl}_{2} \mathrm{O}_{4}\right)$ stebejjimo langeliai (10). Langeliai itaisyti $x / h=9,4 ; 14,8 ; 20,4 ; 39,2(166,312,458$, $932 \mathrm{~mm}$ ) atstumais nuo kanalo pradžios ir $4 \mathrm{~mm}$ aukštyje nuo kanalo dugno. Pro langeli galima matyti $21 \mathrm{~mm}$ vandens aukščio zoną (iš $25 \mathrm{~mm}$ ). Šiame tyrime naudojamo laboratorinio termovizorius darbo diapazonas apima (3-5) $\mu \mathrm{m}$ bangu ilgi. Parenkant optinius langus svarbios buvo ne tik geros optinès savybès, bet ir atsparumas temperatūrai bei atsparumas temperatūros sukeliamiems mechaniniams ittempimams, kietumas, atsparumas ỉbrèžimams ir erozijai. Pasirinkta metalo keramika - Spinelis, naudojamas raketu šiluminio nutaikymo galvutèse [2] ( $>80 \%$ optinis pralaidumas $(0,5-4,5) \mu \mathrm{m}$ bangos ilgio diapazone). Siekiant sumažinti šilumos nuostolius ị aplinką, kanalas izoliuotas $100 \mathrm{~mm}$ storio akmens vatos sluoksniu. Eksperimentinių tyrimų metu garas buvo tiekiamas iš 4 garo generatorių (1). Tiekiamo perkaitinto garo debitas ị kanalą svyruoja nuo 2,02 iki $4,03 \mathrm{~g} / \mathrm{s}$, temperatūra $-120^{\circ} \mathrm{C}$. İ kanalą tekantis garas tiekiamas per rankinio valdymo (2) ir 


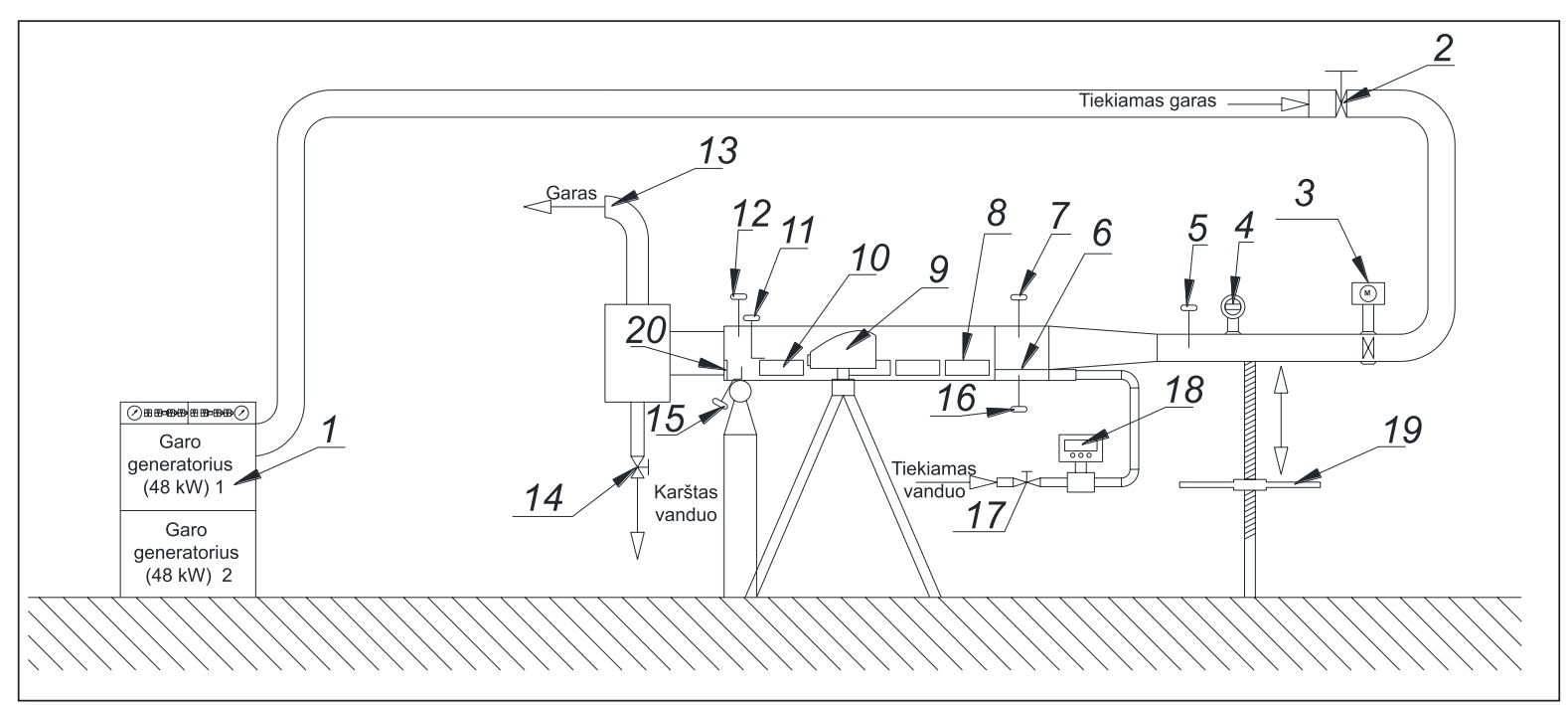

1 pav. Eksperimentinis stendas. 1 - garo generatoriai, 2 - tiekiamo garo rutuliné sklendè, 3 - garo debito valdymo sklendè, 4 - garo debito matuoklis, 5; 7; 11; 12; 15; 16 - K tipo termoporos, 6 - horizontalus peilis, 8 - Spinel IR optinis stebejjimo langas, 9 - infraraudonuju spindulių (IR) kamera SC-5000, 10 - Optinis IR stebëjimo langelis (Spinel $\mathrm{MgAl}_{2} \mathrm{O}_{4}$ ), 13 - garo ištekèjimas, 14 - vandens ištekëjimas, 17 - vandens debito rutulinè sklendè, 18 - vandens debito matuoklis, 19 - stačiakampio kanalo polinkio kampo reguliavimo j̨taisas, 20 - vandens lygio reguliavimo slenkstis

elektrinę (3) sklendes. Rankinio valdymo sklendè buvo naudojama avariniam tiekiamo garo srauto sustabdymui. Elektrine sklende buvo reguliuojamas tiekiamo garo srautas ị kanalą. Tiekiamo garo srautas matuotas Vortex tipo srauto matuokliu (4), garo temperatūra - $\mathrm{K}$ tipo (Cr-Al) termopora (5). Tiekiamo vandens srautas ị kanalą matuotas naudojant elektromagnetini srauto matuoklį (18), o reguliuojamas - naudojant mechaninę balansinę sklendę (17).

Prieš kanalą vandens ir garo debitas yra stabilizuojamas. Naudojant korinę struktūrą pašalinami vandens, garo sūkuriai, o horizontaliu peiliu (6) suformuojamas lygus tarpfazinis paviršius. Korinès struktūros ilgis yra $95 \mathrm{~mm}$, ji sudaryta iš daugybès lygiagrečių kanalèlių, kurių kiekvieno skersmuo $\sim 1 \mathrm{~mm}$. Iškart už korio, $25 \mathrm{~mm}$ aukštyje nuo kanalo dugno, garą nuo vandens skiria $190 \mathrm{~mm}$ ilgio horizontalus peilis, nuo kurio galo prasideda tiesioginè tarpfazinè sąveika. Tokị stabilizavimo principą taiko ir kiti tyrèjai [3]. Siekiant sumažinti garo ir vandens šilumos mainus dar prieš tiesiogini jų kontaktą, horizontalaus peilio apatinè, vandenyje esanti pusé, padengta izoliacine medžiaga. Vandens ir garo ittekèjimo ị kanalą ir ištekèjimo iš kanalo skerspjūviuose temperatūros matuojamos $\mathrm{K}$ tipo (Cr-Al) termoporomis $(7,16$, $12,15)$. Vandens temperatūra kanalo gale matuo- jama 5 termoporomis, kurios itaisytos viena virš kitos kanalo centrineje dalyje. Vanduo ir garas iš kanalo išteka vamzdžiais $(13,14)$. Eksperimentinių tyrimų metu, esant skirtingiems vandens ir garo greičiams, ir siekiant išlaikyti pastovų vandens lygi (25 mm) tiek kanalo pradžioje, tiek ir gale, polinkio kampo reguliavimo ittaisu (19) buvo nuolat reguliuojamas kanalo posvyrio kampas ir užtvaros aukštis (20). Temperatūros profilių matavimai kanale atlikti termovizoriumi SC-5000 (9) taikant termografijos metodą.

Eksperimentinių tyrimų metu buvo atliekami matavimai esant skirtingiems vandens ir garo greičiams. 2 pav. pateikiamas eksperimentinio kanalo skerspjūvio vaizdas. Izoliuoto stačiakampio kanalo apatineje dalyje teka vanduo, jo greitis $\sim 0,014 ; \sim 0,028$ ir $\sim 0,056 \mathrm{~m} / \mathrm{s}$ (debitas 25,50 , 100 l/h). Tiekiamo ị kanalą vandens temperatūra siekè $25{ }^{\circ} \mathrm{C}$. Virš vandens tiekiamas perkaitintas garas, jo temperatūra prieš ịtekant ị kanalą $-\sim 120^{\circ} \mathrm{C}$, o kanalo gale (atsižvelgiant ị vandens ir garo greičius) nukrisdavo iki $\sim 101{ }^{\circ} \mathrm{C}$. Vandens aukštis kanale buvo $25 \mathrm{~mm}$.

Vandens temperatūros profilių matavimo eksperimento metu eiliškumas:

1. Nustatomas (-a) pastovus (-i):

a) ị kanalą tiekiamo garo greitis $-6 \mathrm{~m} / \mathrm{s}$;

b) vandens debitas $-251 / \mathrm{h}(0,014 \mathrm{~m} / \mathrm{s})$; 


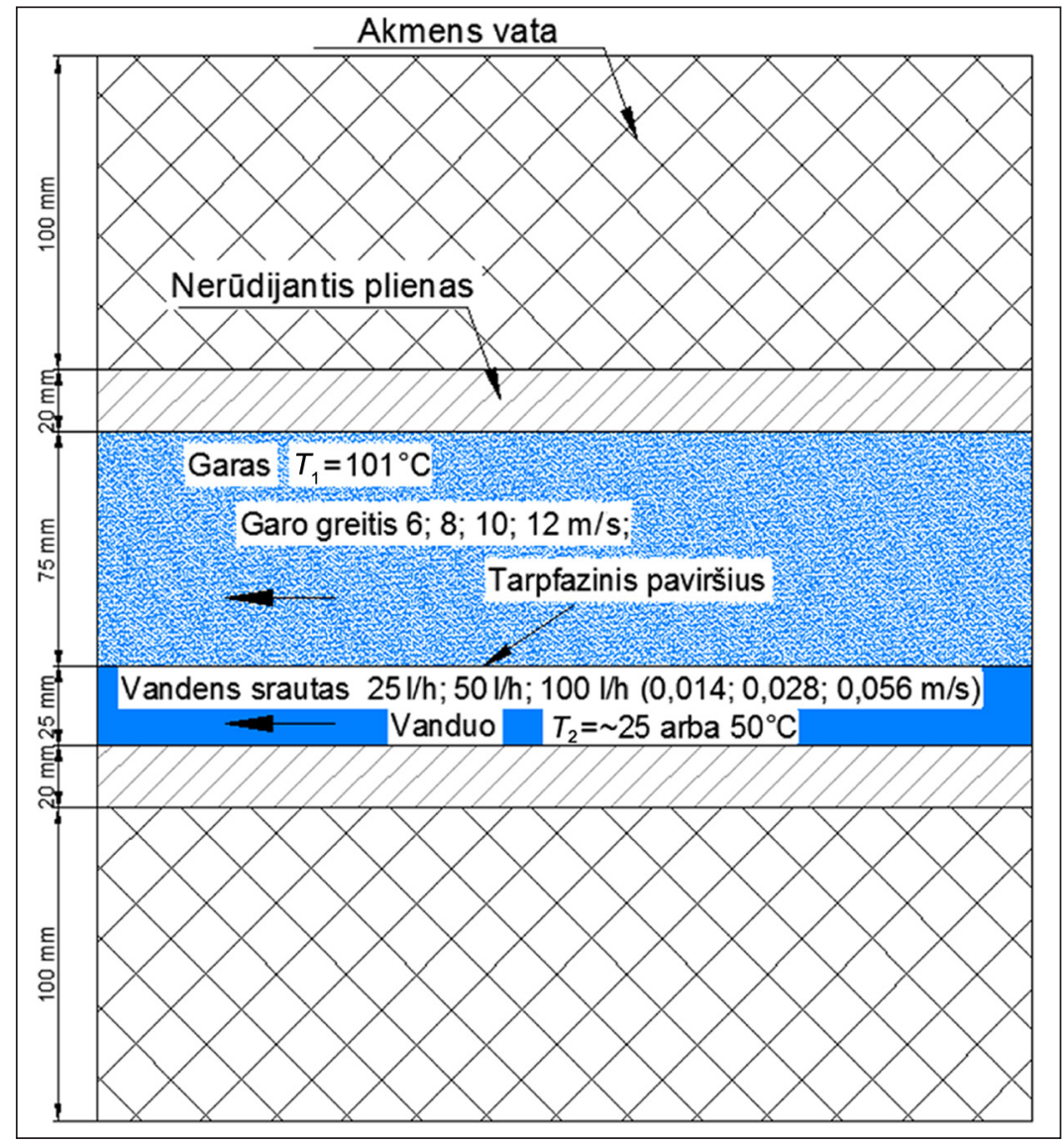

2 pav. Eksperimentinio kanalo skerspjūvis

c) vandens temperatūra $-25^{\circ} \mathrm{C}$;

d) vandens sluoksnio aukštis kanalo pradžioje ir pabaigoje $-25 \mathrm{~mm}$.

2. Eksperimentiniai matavimai pradedami po 3 valandu, kai visa sistema tampa stacionarios būsenos.

3. Vandens temperatūros profiliai (termovizoriumi) matuojami keturiose kanalo vietose $-x / h=9,4 ; 14,8 ; 20,4 ; 39,2$.

4. Matuojama vandens, garo temperatūra kanalo pradžioje ir pabaigoje.

5. Nustatomas tiekiamo ị kanalą vandens debitas $-50 \mathrm{l} / \mathrm{h}$.

6. Vykdomi darbai aprašyti 1 (c, d), 2, 3, 4 punktuose.

7. Toliau atliekami analogiški vandens temperatūros matavimai esant $8,10,12 \mathrm{~m} / \mathrm{s}$ garo greičiams pagal 1-6 punktuose pateiktų darbų sąrašą.

Kiekvieno režimo skirtingose kanalo vietose vandens temperatūros matavimai termovizoriumi buvo vykdomi $30 \mathrm{~s}$ (50 kadrų per sekunde dažniu). Vieno matavimo metu gaunama 1500 kadrų, kurių vandens temperatūros profilių atskirų taškų reikšmès buvo suvidurkintos.
Naudojant gautų vandens profilių atskirų taškų vidutines temperatūras skaičiuojamos vidutinès vandens sluoksnio temperatūros skirtingose kanalo vietose $(x / h=9,4 ; 14,8 ; 20,4 ; 39,2)$ ir esant skirtingoms vandens įtekèjimo temperatūroms (25 ir $\left.50{ }^{\circ} \mathrm{C}\right)$.

Pagal vidutinę vandens temperatūrą skirtingose kanalo vietose nustatomos Reinoldso (toliau $\mathrm{Re})$ kriterijaus reikšmès (Lentelè) daugeliu atvejų rodo laminarinị tekèjimo režimą ir tik kelios pereinamaji $(2300<\operatorname{Re}<4000)$. Tačiau realus (vizualiai stebint vandens tekèjimą) dèl vandens greitinimo, ikaitinimo prie tarpfazinio paviršiaus tekejimas yra pereinamasis ir turbulentinis.

Atliekant Re kriterijaus skaičiavimus buvo priimta, kad vandens greitis visame kanale yra vienodas ir lygus įtekejjimo greičiui ił kanalą. Re kriterijaus skaičiavimai buvo atliekami taip:

$$
\operatorname{Re}=\frac{w_{f} D_{h, f}}{v_{f}}
$$

čia: $w_{f}$ - vandens vidutinis greitis kanalo pradžioje $(\mathrm{m} / \mathrm{s}) ; v_{f}$ - kinematine klampa $\left(\mathrm{m}^{2} / \mathrm{s}\right) ; v_{f}-f(t)$, $t$ - temperatūra $\left({ }^{\circ} \mathrm{C}\right)$. 
Lentelè. Re reikšmės vandenyje esant skirtingoms vandens įtekẻjimo temperatūroms ir skirtingiems atstumams x nuo įtekèjimo

\begin{tabular}{|c|c|c|c|c|c|}
\hline \multirow{3}{*}{$\begin{array}{c}\text { Garo greitis } \\
\mathrm{m} / \mathrm{s}\end{array}$} & \multirow{3}{*}{ Vandens greitis m/s } & \multicolumn{4}{|c|}{ Vandens įtekèjimo temperatūra $25^{\circ} \mathrm{C}$} \\
\hline & & $x / h=9,4$ & $x / h=14,8$ & $x / h=20,4$ & $x / h=39,2$ \\
\hline & & \multicolumn{4}{|c|}{$\operatorname{Re}$} \\
\hline 6 & 0,014 & 527 & 558 & 674 & 1010 \\
\hline 6 & 0,028 & 1040 & 1072 & 1099 & 1578 \\
\hline 6 & 0,056 & 2089 & 2207 & 2283 & 2158 \\
\hline 8 & 0,014 & 497 & 587 & 898 & 1041 \\
\hline 8 & 0,028 & 998 & 1034 & 1230 & 1912 \\
\hline 8 & 0,056 & 2019 & 2051 & 2181 & 2715 \\
\hline 10 & 0,014 & 514 & 852 & 987 & 1039 \\
\hline 10 & 0,028 & 1033 & 1220 & 1648 & 2044 \\
\hline 10 & 0,056 & 1999 & 2190 & 2662 & 3561 \\
\hline 12 & 0,014 & 615 & 952 & 1025 & 1039 \\
\hline 12 & 0,028 & 1606 & 1611 & 1870 & 2079 \\
\hline 12 & 0,056 & 1753 & 2581 & 3106 & 3825 \\
\hline
\end{tabular}

Hidraulinis skersmuo [7]:

$$
D_{h, f}=\frac{4 A_{p, f}}{S_{g}+S_{f}},
$$

čia: $A_{p, f}$ - vandens tèkmès skerspjūvio plotas $\left(\mathrm{m}^{2}\right) ; S_{g}^{p, f}$ - tarpfazinio vanduo / garas paviršiaus perimetras $(\mathrm{m}) ; S_{f}$ - paviršiaus vanduo / kanalo sienelè perimetras $(\mathrm{m})$.

\section{TYRIMŲ REZULTATAI IR JŲ ANALIZĖ}

Vandens temperatūros profiliai esant skirtingiems vandens tiekiamo srauto ir garo itekejimo greičio deriniams buvo matuojami 4 -iuose nustatytuose kanalo skerspjūviuose. 3 pav. vertikalia (raudona) linija pažymètas $x / h=9,4$ skerspjūvis, ties kuriuo buvo matuojamas vandens temperatūros profilis.

Vandens temperatūros profilių matavimo rezultatai pateikti 4, 8, 9 pav. (vandens ittekejjimo temperatūra $25{ }^{\circ} \mathrm{C}$ ). Kiekviename paveiksle yra parodomi vandens temperatūros profiliai skirtingose kanalo vietose ir esant skirtingiems garo tekejimo greičiams.

Esant skirtingam garo greičiui kanale, išmatuotų vandens temperatūros profilių kitimas nèra tolygus kaip būtų esant laminarinei vandens tèkmei. Analizuojant visus išmatuotus vandens
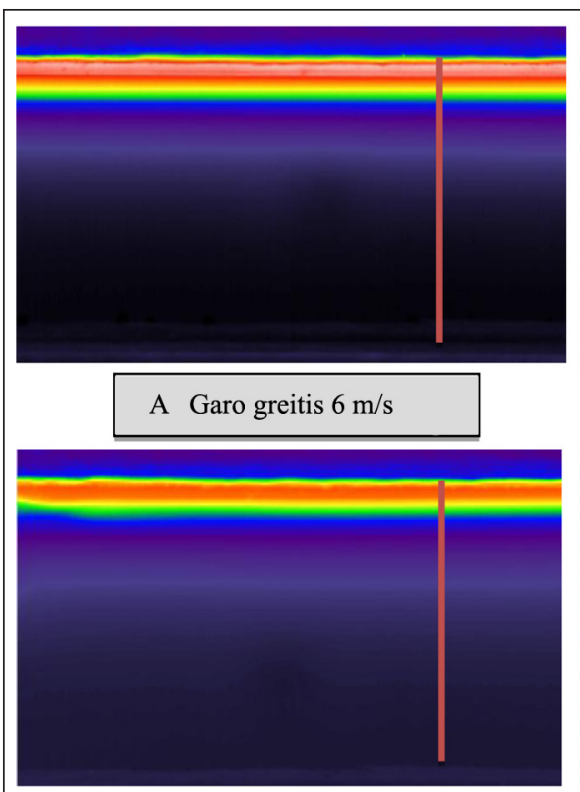

C Garo greitis $10 \mathrm{~m} / \mathrm{s}$

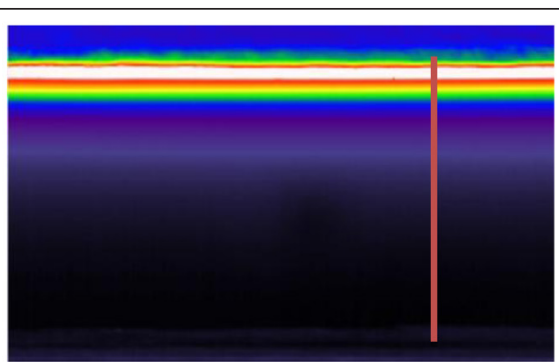

B Garo greitis $8 \mathrm{~m} / \mathrm{s}$

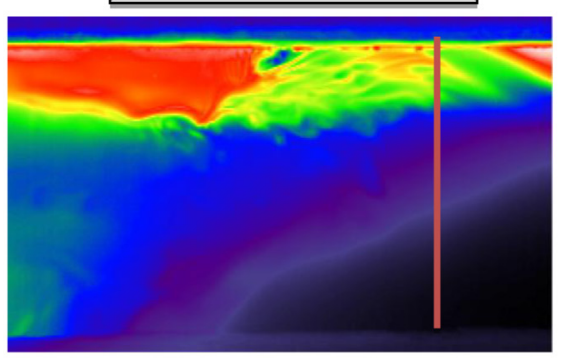

D Garo greitis $12 \mathrm{~m} / \mathrm{s}$
3 pav. Šiluminès nuotraukos garui j̨tekant į kanalą 6, 8, 10 ir $12 \mathrm{~m} / \mathrm{s}$ greičiu, kai vandens greitis $0,014 \mathrm{~m} / \mathrm{s}$, jetekančio vandens temperatūra $25^{\circ} \mathrm{C}$. Vertikali linija žymi vandens temperatūros profilių matavimo vietą ties $x / h=9,4$. Vandens ir garo tekejjimo kryptis yra iš dešinès i kairę 
temperatūros profilius $(4,8,9$ pav.) pagal aukštị nuo tarpfazinio paviršiaus iki kanalo apatinès sienelès, galima įžvelgti iki 4-ių zonų, kurios susiformuoja vandens tūryje esant skirtingiems vandens ir garo tekejjimo debitams (greičiams). Šios zonos parodo vandens temperatūros kitimo greiti, t. y. kokiu greičiu kinta (didejja ar mažeja) temperatūra per vandens sluoksnio aukščio vienetą $\left({ }^{\circ} \mathrm{C} / \mathrm{mm}\right)$. I tipo paviršinès zonos ribos yra $\sim 0,85-1,00$ vandens sluoksnio aukščio. Šioje zonoje vandens temperatūra yra ne tik aukščiausia, bet ir labiausiai kintanti. Giliau prasideda II tipo zona $(\sim 0,70-0,85$ vandens sluoksnio santykinio aukščio), kurioje vandens temperatūros kitimas lètejja. III tipo zona įžvelgtina $0,50-0,70$ gylyje, o apačioje $(\sim 0,25-0,50)$ lieka IV tipo zona. Per III ir IV zonas temperatūros kitimas yra mažiausias. Kai kuriuose profiliuose galima išskirti tik dvi zonas, tačiau pastarujų temperatūra nenukrenta žemiau $90{ }^{\circ} \mathrm{C}$. Toks zonavimas parodo bendras tekèjimo charakteristikas, todèl skirtingus tekèjimo režimus aptarsime išsamiau.

Iki $x=0$ vanduo su garu neturi tiesioginio kontakto. Nuo $x=0$ kondensuojantis garui ị vandens paviršių perduodama fazinio virsmo šiluma ir soties temperatūros kondensato masè. I kanalą tiekiamas garas yra truputi perkaitintas (temperatūra $\sim 120{ }^{\circ} \mathrm{C}$ ) ir labai mažai kondensuojasi ant sienelių, tačiau kondensacijai ant vandens paviršiaus šis perkaitinimas ittakos beveik neturi [4]. Ženklios įtakos pradinei kondensacijai neturi ir pradinio fazių temperatūrų skirtumo dydis, nes, vos pradèjęs sąveikauti su garu, laminariškai tekančio vandens paviršius iškart pasiekia sotinimo temperatūrą. Kadangi $\mathfrak{i}$ kanalą tiekiamame gare beveik nèra kondensaciją ribojančių nesikondensuojančių dujų, t. y. dvifazio tekéjimo šiluminę nepusiausvirą palaiko prastas šilumos nuvedimas nuo vandens paviršiaus i gilumą. Taigi, svarbiausias nagrinëjamo dvifazio besikondensuojančio tekejimo pirminis parametras lieka garo ir vandens ịtekejjimo ị kanalą greičių skirtumas. Greičiau tekantis garas pirmiausia mechaniškai trikdo vandens paviršių, o gravitacija, klampa ir paviršiaus itempis ji stabilizuoja. Gravitacines bangas slopina paviršiaus ittempis, o kapiliarines labiausiai slopina klampa. Vandens paviršiaus įtempis labai priklauso nuo temperatūros, tačiau viso tarpfazinio paviršiaus kanale temperatūra yra arti soties. Todèl kondensacijos atveju paviršiaus įtempis nelaiko- mas kintamuoju, tačiau klampa iškart po paviršiumi ir giliau kinta iki 3,5 karto. Būtent klampos sumažèjimas ir "paleidžia“ visą vietinių tarpfazinès sąveikos reiškinių su teigiamais grį̌tamaisiais ryšiais kaskadą turbulencija > kondensacijos intensyvumas > tarpfazinis greitis. Kartu tekedami garas ir vanduo abipusiai sąveikauja. Nuo pat tiesioginès sąveikos pradžios $(x=0)$ atsiradęs tarpfazinis paviršius yra veikiamas tarpfazinès trinties jèga, kurios stiprumas priklauso nuo vietinio tarpfazinio greičio bei kitų parametrų ir vykstant kondensacijai vandens paviršius garo tèkmei tampa iš dalies pralaidžia sienele. Todèl esant pastoviam vidutiniam fazių greičių skirtumui, vietinè vandens paviršiaus greičio reikšmė prie tarpfazinio paviršiaus gali kisti atsižvelgiant $\mathfrak{i}$ kondensacijos intensyvumą. Dèl tarpfazinès sąveikos pasroviui besikeičiančių (nuo pradinių garo ir vandens įtekejimo ị kanalą) sąlygų vietinis tarpfazinis greitis (angl. slip velocity) iš pradžių mažèja, nes gerokai greičiau tekantis garas dèl trinties stabdomas ir pats tekejjimo kryptimi „velka“ vandens paviršių. Tarpfazinio paviršiaus greitis išilgai kanalo nuolat didèja igreitindamas ir po paviršiumi esantị vandeni, todèl vietinis tarpfazinis greitis turètų mažèti toliau. Suintensyvejjusi kondensacija padidina garo greitị prie pat vandens paviršiaus, ir vietinis tarpfazinis greitis padideja, o kondensacijai nuslopus vèl sumažeja [8]. Šiluminèje nuotraukoje 3 pav. esant $12 \mathrm{~m} / \mathrm{s}$ garo tekejjimo greičiui matoma suaktyvejusios turbulencijos zona (pažymètina, kad turbulencija po tarpfaziniu paviršiumi prasideda anksčiau nei jo bangavimas). Atsižvelgiant i aptartus vykstančiu procesų tarpusavio ryšius, turbulenciją sužadinanti tarpfazinès sąveikos seka turètų būti tokia:

1. Kylant vandens temperatūrai mažèja jo klampa ir tankis.

2. Veikiant Archimedo jejgai karštas mažesnio tankio vanduo laikosi prie paviršiaus ir po juo susiformuoja plona temperatūros gradiento zona (I zona).

3. Šiame sluoksnyje vis kylant temperatūrai mažèja klampa ir Re didejja sparčiau, palyginti su giliau ir mažesniu greičiu tekančiu šaltesniu vandeniu. Po tarpfaziniu paviršiumi įvyksta turbulencijos sužadinimas.

4. Mažiau klampus paviršinis vanduo vis labiau igreitinamas virš jo tekančio garo. Turbulencija plinta gilyn ir, atnaujindama paviršiu 
(angl. surface renewal) šaltesniu vandeniu, intensyvina kondensaciją.

5. Intensyvejant kondensacijai vietinis virš vandens paviršiaus tekančio garo greitis dideja [8] ir dar didesne jèga stumia tarpfazini paviršiu.

6. Vandenyje susiformuoja ne tik temperatūros, bet ir tekejjimo greičio gradientas. Dèl pagreitejjimo prie paviršiaus vanduo apačioje pradeda judèti lèčiau ir net tekèti atgal.

7. Augantys sūkuriai destabilizuoja tarpfazini paviršiu ir "užgriebia“ vis gilesnius vandens sluoksnius.

Aptarta grị̌žtamais teigiamais ryšiais susijusių procesų visuma paaiškina pradžioje lèto kondensacijos proceso eksponentini išaugimą. Šio reiškinio aktyviausios fazès (gerai matomos 3 pav.) pradžia kanale priklauso nuo garo ir vandens greičių derinio. Tačiau kondensacijos intensyvumo ir tarpfazinès sąveikos eksponentini augimą staiga sustabdo vandens šilimas. Toliau tekant kanalu garo-vandens šiluminè nepusiausvira sparčiai mąžta ir, nuslopus kondensacijai, tarpfazinio paviršiaus šlytis vẻl sumažeja [8]. Kanalo pabaigoje (pvz., $4 \mathrm{~A}$ ir 5A pav. $x / h=39,2$, garo greitis $6 \mathrm{~m} / \mathrm{s}$, vandens $0,014 \mathrm{~m} / \mathrm{s}$ ) vandens temperatūros gradientas likęs labai mažas, bet jo pakanka, kad termovizoriumi vis dar būtų galima registruoti maišymąsi ir sūkurius. Tačiau matomas vandens maišymosi intensyvumas ir sūkurių dydis yra nepalyginamai mažesni nei aktyvaus turbulencijos sužadinimo zonoje.

Turbulencijos sužadinimas su kondensacijos intensyvumo piku prasideda ne iškart už $x=0$, o palengva plètojasi pasroviui. Todèl norint pamatyti, kaip šiluminè nepusiausvirinè dvifazè tèkmè

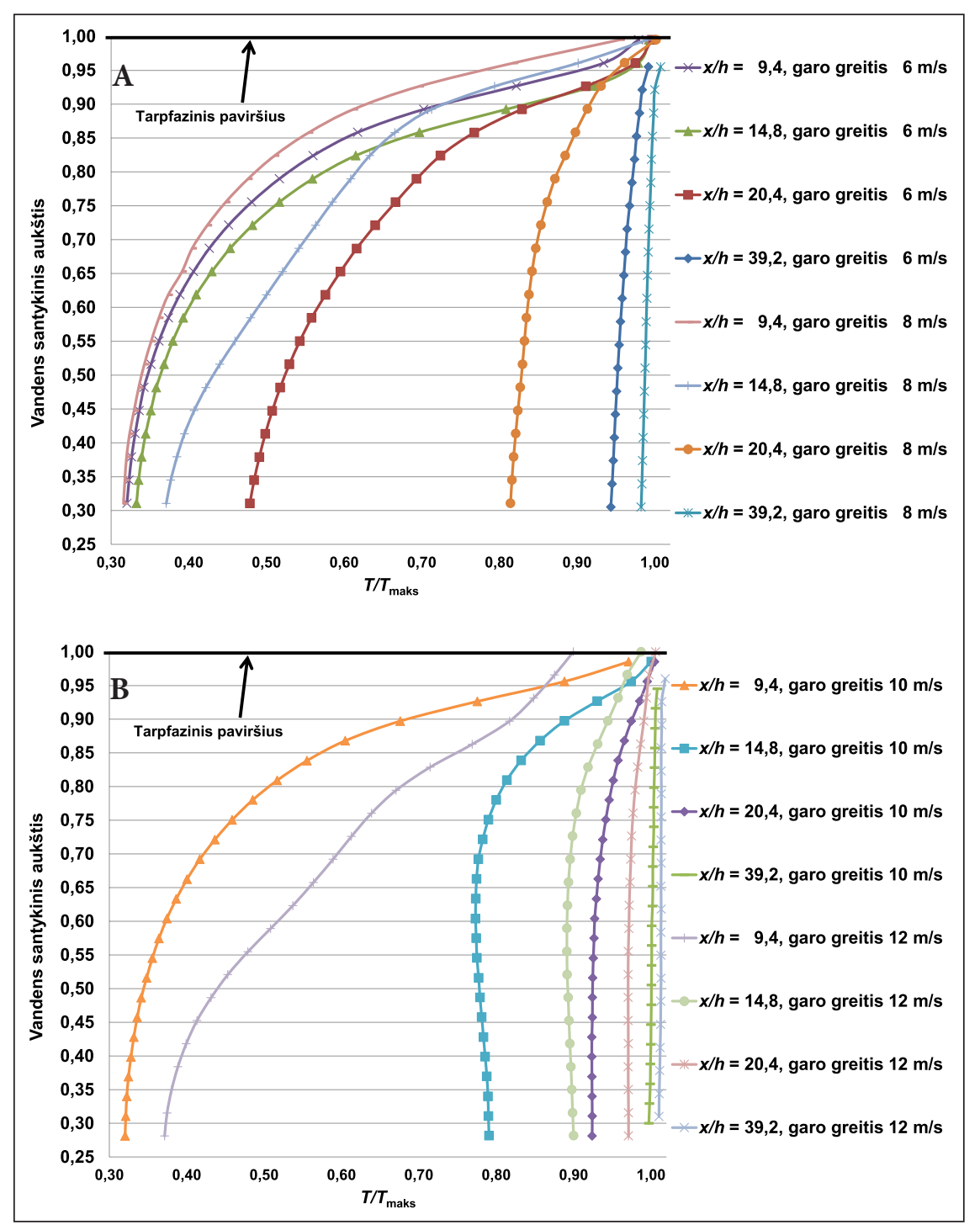

4 pav. Vandens temperatūros profiliai esant pastoviam vandens greičiui $0,014 \mathrm{~m} / \mathrm{s}$, vandens ìtekèjimo temperatūrai $25^{\circ} \mathrm{C}$ ir skirtingam atstumui nuo kanalo pradžios $(x / h=9,4$; $14,8 ; 20,4 ; 39,2)$ bei garo greičiui A $(6 ; 8 \mathrm{~m} / \mathrm{s}), B(10 ; 12 \mathrm{~m} / \mathrm{s})$ 


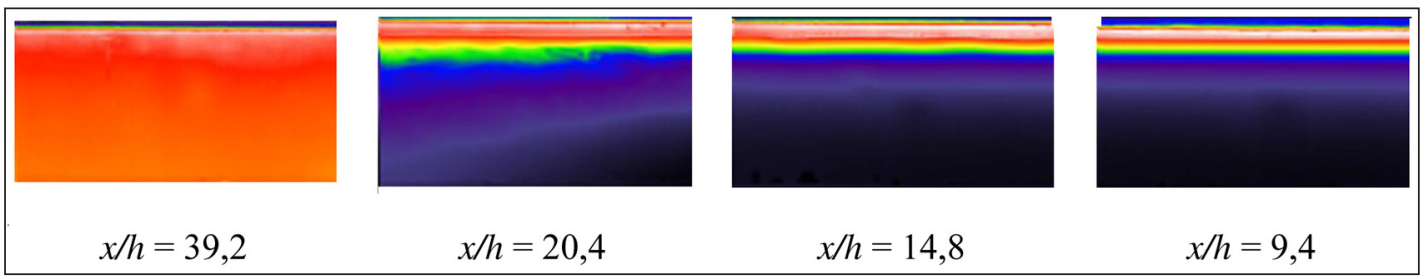

5 pav. Šilumines nuotraukos esant $0,14 \mathrm{~m} / \mathrm{s}$ vandens ir $6 \mathrm{~m} / \mathrm{s}$ garo j̇tekèjimo greičiams, kai vandens įtekèjimo temperatūra $25^{\circ} \mathrm{C}$, trijose kanalo vietose $x / h=9,4 ; 14,8 ; 20,4 ; 39,2$. Tekejjimo kryptis yra iš dešinės j kairę

sužadina turbulenciją vandenyje, verta apžvelgti režimą, kai aktyviausia sužadinimo fazè vyksta toli nuo kanalo pradžios. 5 pav. pateiktos skirtingu atstumu nuo kanalo pradžios padarytos šiluminès nuotraukos, esant $6 \mathrm{~m} / \mathrm{s}$ garo ir $0,014 \mathrm{~m} / \mathrm{s}$ vandens $\left(25^{\circ} \mathrm{C}\right)$ ịtekèjimo ì kanalą greičiams. Matoma, kad vandens tèkmè išliko laminari iki $x / h=20,4$ kanalo vietos. Dèl vidutinès vandens temperatūros padidejjimo skaičiuota Re pakilo iki 600 , tačiau nuo $x / h=20,4$ prie tarpfazinio paviršiaus vietiškai pradejo formuotis sūkuriai, ir vidutinè vandens temperatūra taip pat pradèjo sparčiai kilti (4A pav.). Tëkmès turbulencijos sužadinimas prasidejęs ties $x / h=20,4$, ties $x / h=39,2$ jau yra nuslopęs. Ties $x / h=39,2$ prie apatinès sienelès vizualiai stebimas matomas lètas atbulinis tekejimas. Jis atsiranda dèl slenkstelio itaisyto kanalo gale. Slenkstelio pagalba yra palaikomas vandens aukštis kanale. Taigi, kai garo tèkmė igreitina arti paviršiaus tekantị vandenį, kartu išauga ir vietinis vandens debito tankis. Kadangi bendrasis vandens debitas yra vienodas bet kuriame kanalo skerspjūvyje, tai didejjant vietiniam vandens debitui prie paviršiaus mažèja vietinis debitas apačioje. Dar toliau didejjant vandens greičiui prie tarpfazinio paviršiaus, prie apatinès sienelès greitis mažeja iki nulio ir galiausiai tampa neigiamas. Tokiu būdu pradeda formuotis vandens sluoksnyje vidinis cirkuliacijos ratas. Kitaip sakant, vanduo viršutinèje vandens sluoksnio pu- sèje teka ištekejjimo kryptimi (link kanalo galo), o ties dugnu - atvirščiai.

Tarpfazinès sąveikos sukeliamos vidinès (vandens) cirkuliacijos rato pradžia (kanale) turètų sutapti su turbulencijos sužadinimo aktyviausia faze. Cirkuliacijos rato pradžioje vanduo iš dugno kyla aukštyn ir dẻl anksčiau aprašytų procesų ivvyksta vandens tèkmès turbulencijos sužadinimas. Šis grįžtamasis tekèjimas yra vienas iš tarpfazinès sąveikos dalyvių, grižtamaisiais ryšiais susijęs su kitais veiksniais. Kol kas trūksta duomenų atsakyti ị klausimą, ar pašalinus grị̌žtamo tekejimo susidarymo galimybę turbulencijos sužadinimas vis tiek vyktų. Norint ištirti, reikètų gerokai padidinti vandens bendrajj vandens srautą, plečiant vandens pratekèjimo skerspjūvị ar / ir greiti. Tam reikia pakeisti eksperimentinio kanalo konstrukciją. Esamų galimybių ribose $(0,014-0,056) \mathrm{m} / \mathrm{s}$ didinant vandens greitị ir esant pastoviam garo ịtekejjimo ị kanalą greičiui, turbulencijos sužadinimo pradžia slenka tolyn nuo kanalo pradžios. Garo greičio padidinimas priešingai - turbulencijos sužadinamą labai smarkiai perslenka arčiau kanalo pradžios (5 ir 6 pav).

Pavyzdžiui, kai garas ị kanalą įteka $8 \mathrm{~m} / \mathrm{s}$ (vanduo $0,014 \mathrm{~m} / \mathrm{s}, 25^{\circ} \mathrm{C}$ ) iki $x / h=9,4$ vandens tèkmè išlieka visiškai laminarinè ( 6 pav.). Ties $x / h=14,8$ prasideda turbulencijos sužadinimas. Suintensyvéja šilumos perdavimas nuo tarpfazinio paviršiaus ị vandens gilumą.

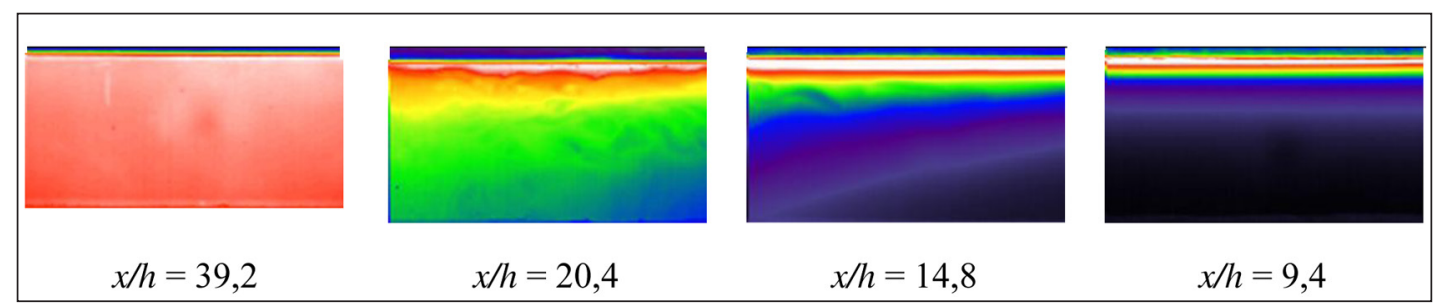

6 pav. Šiluminès nuotraukos esant $0,14 \mathrm{~m} / \mathrm{s}$ vandens ir $8 \mathrm{~m} / \mathrm{s}$ garo įtekejimo greičiams, kai vandens įtekejimo temperatūra $25^{\circ} \mathrm{C}$, trijose kanalo vietose $x / h=9,4 ; 14,8 ; 20,4 ; 39,2$. Tekejjimo kryptis yra iš dešinės j̨ kairę 
Ties $x / h=20,4$ šiluma vis dar efektyviai yra nuvedama ị vandens gilumą. Ties $x / h=39,2$ per visą aukšti vanduo jau beveik pasiekia sotinimo temperatūrą (temperatūros lauke nebèra ženklių gradientų).

Garo itekmès greiti kanale padidinus iki $10 \mathrm{~m} / \mathrm{s}$ (4B pav.), vandens temperatūros profilio reikšmès ties $x / h=9,4$ beveik sutampa su išmatuotomis temperatūros reikšmèmis esant 6 bei $8 \mathrm{~m} / \mathrm{s}$. Ivertinus vandens tekejjimo režimą buvo nustatyta, jog jis turètų būti laminarinis. Tačiau vizualiniai vandens stebejimai ir temperatūrinis laukas parodè, jog realus vandens tekèjimas yra pereinamajame ar turbulentiniame režime.

Stebint ties $x / d=14,8$ nufilmuotą temperatūros lauko kitimą (7 pav. pateiktas vienas kadras) matomas sudètingas turbulentinis vandens tekèjimas su banguojančiu tarpfaziniu paviršiumi ir gerokai didesniu greičiu prie paviršiaus nei gilumoje. Vandens tèkmès nešamų prie paviršiaus generuojamų sūkurių karšto vandens šuorai perneša šilumą gilumon ị vandenị. $O$ link paviršiaus išstumia didesnio tankio šalto vandens šuorus. Mažas $25 \mathrm{~mm}$ vandens gylis yra palankus. Be to, prie paviršiaus sugeneruoti dideli sūkuriai artéjant prie dugno iggauna trimati pavidalą - vyksta ir skersinis tekejjimas. Dèl didelio vandens greičio (prie paviršiaus) ir lygio palaikymo vykstanti vidine vandens cirkuliacija kanale tam tikrame $x / h$ intervale sukuria unikalias termohidromechanines sąlygas, kai atbulinè vandens tèkmè kanalo apačioje yra aukštesnès temperatūros nei ties viduriu. Tai gerai parodo išmatuotas temperatūros profilis 4 ir 7 pav. ties $x / h=14,8$ (kai garo ittekmès greitis $10 \mathrm{~m} / \mathrm{s}$ ). Prie tarpfazinio paviršiaus vandens temperatūra kaip ir ankstesniais atvejais kinta sparčiausiai; $0,95-0,70$ lygyje temperatūra mažejja iki žemiausios; $0,70-0,25$ lygyje temperatūra vèl kyla. Ties $x / h=20,4$ (garas $10 \mathrm{~m} / \mathrm{s}$ ) išmatuotame profilyje vandens temperatūra apačioje beveik visiškai vienoda iki pat 0,55 lygio. Iš to galima spręsti, kad vanduo ten teka turbulentiškai. Ties $x / h=39,2$ visas vanduo jau beveik pasiekia sotinimo temperatūrą.

Garo ịtekmès greitị padidinus iki $12 \mathrm{~m} / \mathrm{s}$, nors vidutinis Re rodo laminarinį tekẻjimo režimą, tačiau vandens tekèjimas nuo $x / d=9,4$ per visą tekejjimo skerspjūvị yra turbulentinis. Išmatuoti temperatūros profiliai aiškiai parodo tarpfazinio paviršiaus bangavimą ir sūkurius, o apatinèje kanalo dalyje - ir atbulinį tekèjimą. Vidinès vandens cirkuliacijos rato pradžioje (kanale) padugne grižtantis vanduo susiduria su laminariškai ittekančiu šaltu vandeniu. Besimaišydamos priešpriešinès srovès kyla link tarpfazinio paviršiaus. Tarp i̇ viršų kylančių susidūrusių priešpriešinių vandens srovių riboje temperatūros skirtumas siekia iki $10^{\circ} \mathrm{C}$. Ties $x / h=9,4$ vandens temperatūra prie paviršiaus yra apie $10{ }^{\circ} \mathrm{C}$ mažesné negu prieš tai aptartų profilių $(6,8$ ir $10 \mathrm{~m} / \mathrm{s}$ garo ittekmès), nors kondensacija intensyviausia ir vandeniui perduodamos šilumos srautas didžiausias. Ties $x / d=14,8$ didžiausia temperatūra prie tarpfazinio paviršiaus yra artima soties, o gilumoje kinta mažai, tačiau žemiausia temperatūra yra ne apačioje, o jos profilis yra panašus $\mathfrak{i}$

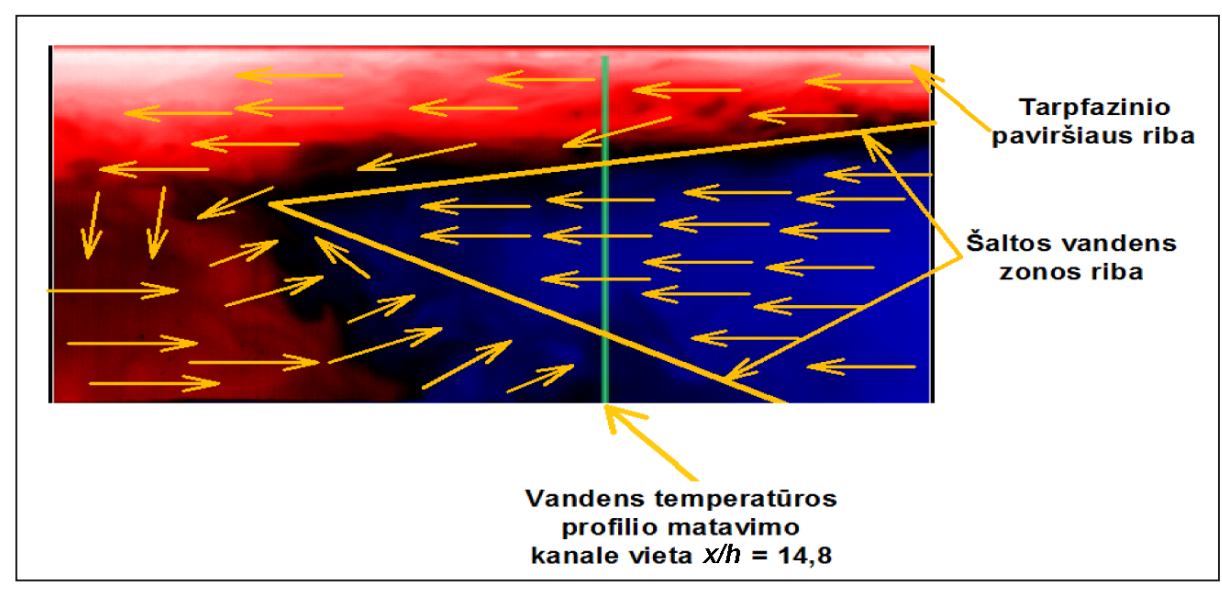

7 pav. Filmuotos medžiagos fragmentas esant $10 \mathrm{~m} / \mathrm{s}$ garo ir $0,014 \mathrm{~m} / \mathrm{s}$ vandens įtekejimo į kanalą greičiams $x / h=14,8$ skerspjūvyje. Vektorių kryptis rodo vyraujančią vandens tekèjimo kryptį, tačiau jų ilgis nẻra proporcingas vandens tekèjimo greičiui. 
čia išmatuotą esant $10 \mathrm{~m} / \mathrm{s}$ garo ịtekmei. Abiem atvejais vandens tèkmès dinaminè struktūra panaši - dèl greito vandens tekejjimo prie tarpfazinio paviršiaus susidaro intensyvi turbulencija ir bangavimas, o kanalo apačioje vyksta atbulinis pulsuojantis tekejimas. Ties $x / d=20,4$ vandens vidutinè temperatūra aukšta ir gradientai maži, tačiau temperatūros profilis ir tekejjimo struktūra išlieka analogiški. Ties $x / h=39,2$ vandens temperatūra per visą vandens sluoksnio aukštị pakilusi iki sočiai artimos.

Ištyrus $6,8,10$ ir $12 \mathrm{~m} / \mathrm{s}$ garo ir $0,014 \mathrm{~m} / \mathrm{s}$ vandens $\left(25^{\circ} \mathrm{C}\right)$ įtekèjimo ị kanalą greičių derinius, buvo gauti tokie rezultatai:

1. Turbulencijos sužadinimo atsiradimas ir vieta priklauso nuo garo ir vandens tekejimo greičių skirtumo.
2. Didinant garo ịtekmès greitị turbulentinio sužadinimo zona artëja link fazių kontakto pradžios. Padidinus tiekiamo vandens greiti du kartus nuo $0,014 \mathrm{iki} 0,028 \mathrm{~m} / \mathrm{s}$ ( $8 \mathrm{~A}$ pav.), vandens tekejjimas esant $6 \mathrm{~m} / \mathrm{s}$ garo ittekejjimo greičiui ties $x / d=9,4$ ir ties $x / d=14,8$ išliko laminarinis. Esant laminariniam tekejjimui šiluma gilesniems vandens sluoksniams perduodama tik laidumu, nes kitus šilumos perdavimo būdus riboja vandeni veikiančios gravitacinès jègos, atsirandančios dèl vandens temperatūros, tankio bei klampos gradientų. Šiltesnis, mažesnès klampos ir mažesnio tankio vanduo teka tik ties tarpfaziniu paviršiumi. Tačiau tiekiamo vandens greičio padidinimas 2 kartus (nuo 0,014 iki 0,028 m/s) pastebimos ittakos šilumos perdavimui $\mathfrak{i}$ gilesnius vandens sluoksnius neturi. Esant dvigubai didesniam vidutiniam

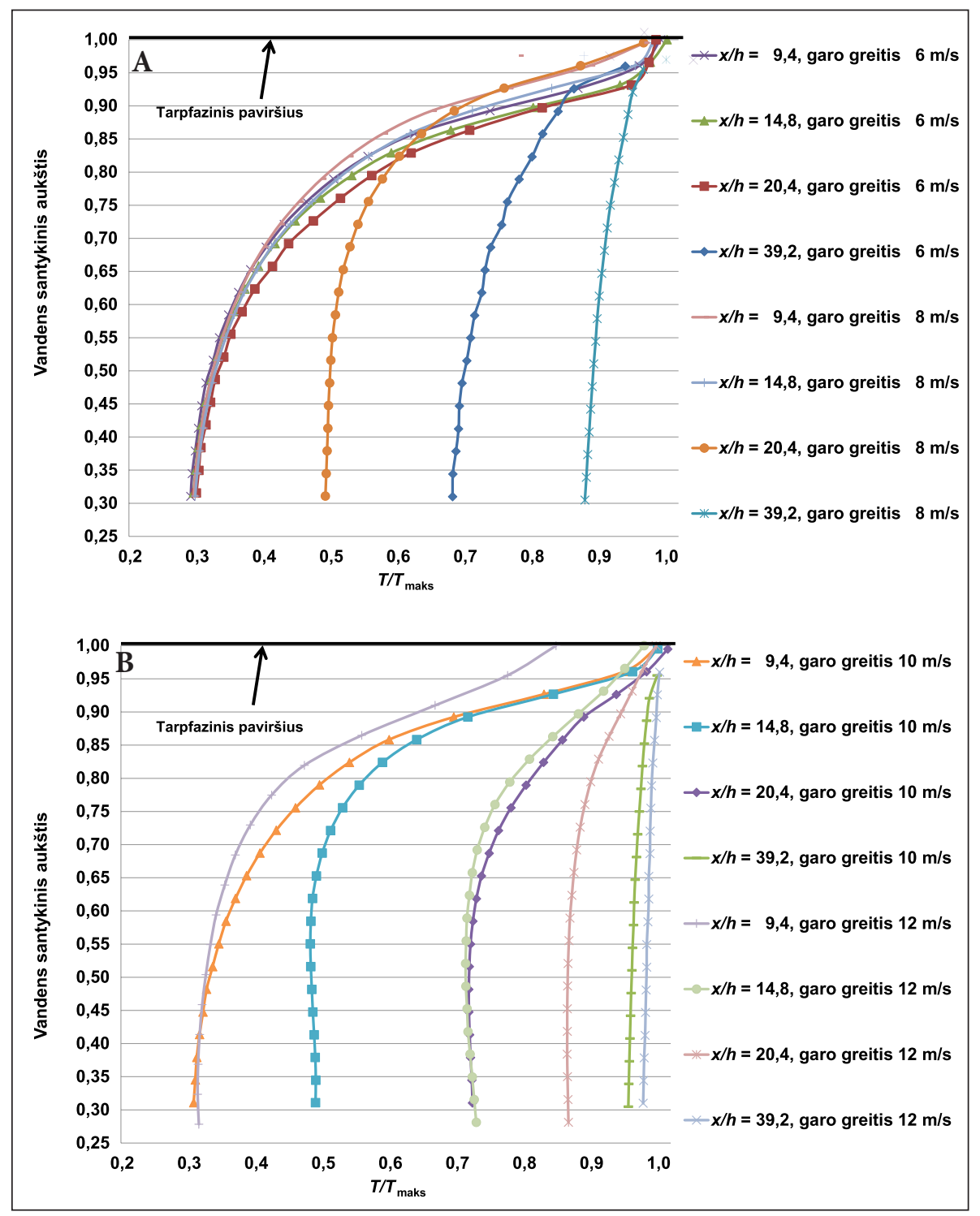

8 pav. Vandens temperatūros profiliai esant pastoviam vandens greičiui $0,028 \mathrm{~m} / \mathrm{s}$, vandens jitekèjimo temperatūrai $25^{\circ} \mathrm{C}$ ir skirtingam atstumui nuo kanalo pradžios $(x / h=9,4$; $14,8 ; 20,4 ; 39,2)$ bei garo greičiui A $(6 ; 8 \mathrm{~m} / \mathrm{s}), B(10$; $12 \mathrm{~m} / \mathrm{s}$ ) 
vandens tekëjimo greičiui tiek pat sutrumpéjo kondensacijos ị elementarų skerspjūvio tūrelị laikas. Todèl buvę maži vandens temperatūros profilių skirtumai ties $x / d=9,4$ ir 14,8 sumažèjo iki beveik visiško sutapimo ( $4 \mathrm{~A}$ ir $8 \mathrm{~A}$ pav.). Ties $x / h=20,4$ kyla silpnas tarpfazinio paviršiaus bangavimas. Temperatūros reikšmès kilsteli nedaug, tačiau čia prasidedantis turbulencijos sužadinimas pasroviui plinta i̇ vandens gilumą. Ties $x / h=39,2$ tarpfazinis paviršius banguoja stipriau nei ties 20,4, arti dugno matoma stagnacija ir labai lètas atbulinis tekejimas. Temperatūros profilis 0,95-1,00 lygyje beveik toks pat, kaip ir prieš tai išmatuotieji $(x / h=9,4,14,8,20,4)$. Žemiau $(0,25-0,95)$ išmatuota temperatūra gerokai aukštesnè nei prieš tai buvusiuose skerspjūviuose. Tai rodo, kad turbulencija gilumoje su paviršiaus bangavimu išlaiko toki pat didelị temperatūros gradientą prie paviršiaus, kondensacijos intensyvumas nemažeja, nors vidutinè vandens temperatūra kyla.

Padidinus garo įtekmès greitị nuo 6 iki $8 \mathrm{~m} / \mathrm{s}$, vanduo $\left(0,028 \mathrm{~m} / \mathrm{s}, 25{ }^{\circ} \mathrm{C}\right.$ itekmè) ties $x / h=9,4$ teka laminariškai. Vandens temperatūros profilis sutampa su $6 \mathrm{~m} / \mathrm{s}$ garo įtekmès atveju. Toliau ties $x / h=14,8$ temperatūros profilis pakinta nežymiai. Vanduo gilumoje tebeteka laminariškai, tačiau paviršius protarpiais suvirpa (panašiai kaip ir esant $6 \mathrm{~m} / \mathrm{s}$ garo ittekmei ties $x / h=20,4)$. Šiuos pavienius virptelèjimus sukelia kondensato lašai, nutekantys nuo kanalo sienelès ir kartais sutrikdantys lygų tarpafazinị vandens ir garo paviršiu prie sienelès. Tarp $x / h=14,8$ ir 20,4 vandenyje prasideda turbulencijos sužadinimas. Turbulencija ties $x / h=20,4$ yra apèmusi visą vandens tékmès gyli,

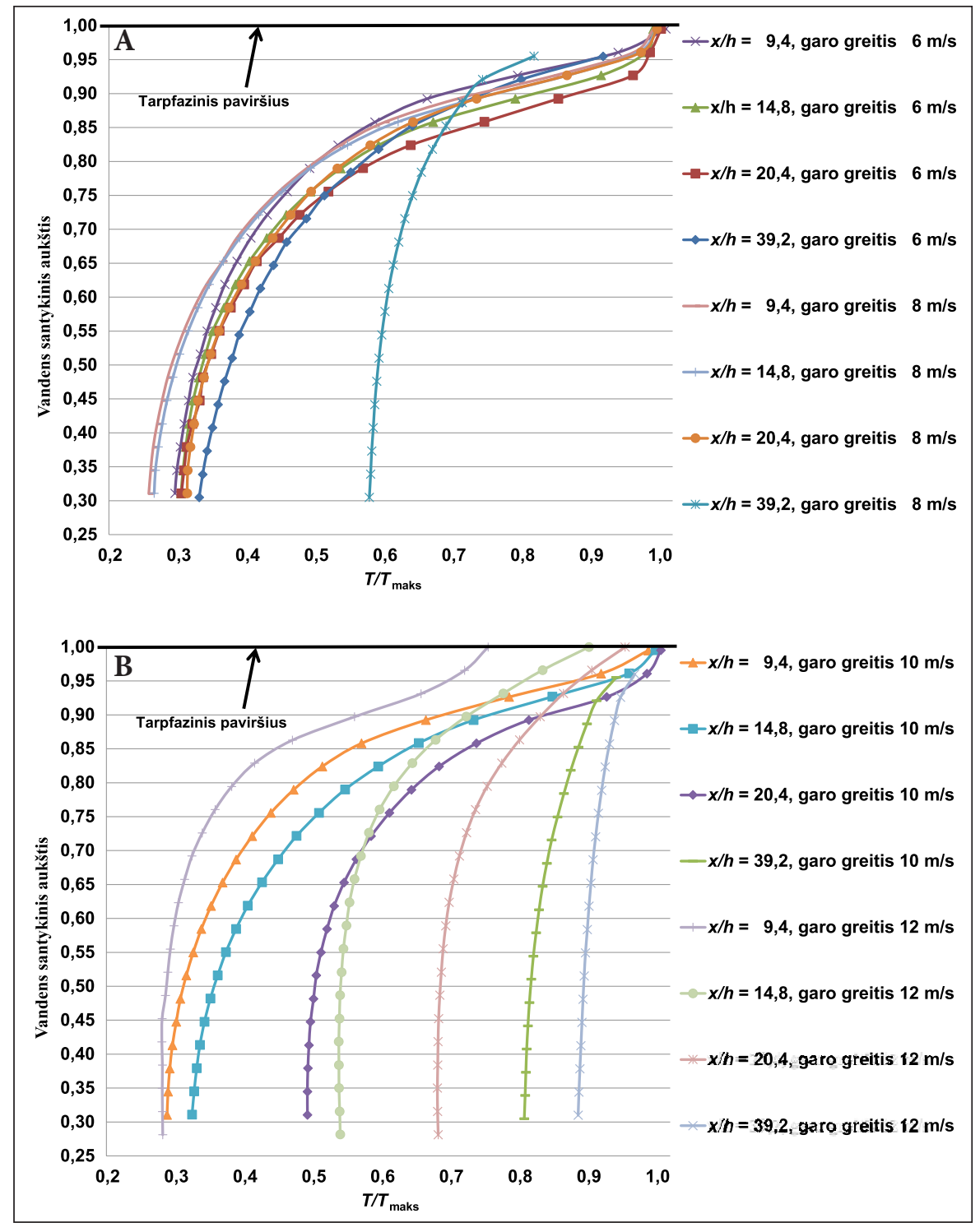

9 pav. Vandens temperatūros profiliai esant pastoviam vandens greičiui $0,056 \mathrm{~m} / \mathrm{s}$, vandens jejjimo temperatūrai $25^{\circ} \mathrm{C}$ ir skirtingam atstumui nuo kanalo pradžios $(x / h=9,4$; $14,8 ; 20,4 ; 39,2)$ bei garo greičiui A $(6 ; 8 \mathrm{~m} / \mathrm{s}), B(10$; $12 \mathrm{~m} / \mathrm{s}$ ) 
generuojami dideli sūkuriai. Šiluma efektyviai nuvedama $\mathfrak{t}$ vandens gilumą, todèl dugne vandens temperatūra pakilusi iki $0,5 \mathrm{~T} / T_{\text {maks }}$ o temperatūros gradientas iki 0,5 vandens aukščio kanale labai mažas. Palyginus ties $x / h=9,4 ; 14,8$ ir 20,4 išmatuotus vandens temperatūros profilius, matoma, kad 0,9-1,0 lygyje temperatūros sutampa, todèl ir šilumos nuvedimo nuo tarpfazinio paviršiaus ị vandens gilumą intensyvumas išlieka pastovus.

10 ir $12 \mathrm{~m} / \mathrm{s}$ (8B pav.) garo ittekejjimas, kaip ir esant vandens ittekèjimui $0,014 \mathrm{~m} / \mathrm{s}$, sukelia vidinę vandens cirkuliaciją kanale, atsispindinčią temperatūros profiliuose ne tik ties $x / d=14,8$, bet ir ties $x / d=20,4$.

9A pav. parodyta, kad padidinus dvigubai vandens srautą (itekmès greitis $0,056 \mathrm{~m} / \mathrm{s}$ ), $6 \mathrm{~m} / \mathrm{s}$ garo ịtekmès atveju turbulencijos sužadinimas nepasireiškia. Ties visais keturiais $x / h$ išmatuoti vandens temperatūros profiliai kinta nedaug, išlaikydami beveik vienodą formą. Tačiau padidinus garo įtekmę iki $8 \mathrm{~m} / \mathrm{s}$, turbulencija sužadinama intervale tarp $x / h=20,4$ ir 39,2. Toliau didinant garo ịtekmès greiti $(10,12 \mathrm{~m} / \mathrm{s})$ turbulencijos sužadinimas prasideda vis arčiau kanalo pradžios, intensyvaus maišymosi intervalas platejja (kaip ir vandeniui įtekant 0,0139 bei $0,028 \mathrm{~m} / \mathrm{s}$ greičiu), nes apima visą likusị kanalo ilgị (9B pav.). Ties $x / h=9,4 ; 14,8$ ir 20,4 (garas $12 \mathrm{~m} / \mathrm{s}$ ) bei $x / d=39,2$ (garas $10 \mathrm{~m} / \mathrm{s}$ ) prie pat vandens paviršiaus išmatuota vidutinè temperatūra yra žema dèl stipraus tarpfazinio paviršiaus bangavimo. Taigi, didinant tiekiamo garo greitį turbulencijos sužadinimas slenka ị kanalo pradžią, o didinant tiekiamo vandens srautą - i kanalo pabaigą.

\section{IŠVADOS}

Atlikus stratifikuoto dvifazio besikondensuojančio vienakrypčio tekejjimo uždarame stačiakampiame kanale vandens temperatūros laukų matavimus tèkmès netrikdančiu metodu, daromos šios išvados:

1. Vandens temperatūrų matavimo metodika igalina vandens temperatūros profilius pasienio sluoksnyje matuoti didele raiška (80 taškų $1 \mathrm{~mm}^{2}$ ).

2. Eksperimentiškai išmatavus vandens temperatūros profilius esant skirtingiems garo ir vandens tekejjimo greičiams nustatyta, kad šilu- mos nuo tarpfazinio paviršiaus nuvedimas ị vandens gilumą vyksta netolygiai. Tekantis vandens sluoksnis einant nuo laisvojo jo paviršiaus link apatinès sienelès gali turèti iki 4 -ių zonų, atsižvelgiant ị temperatūros kitimo greitị.

3. Virš vandens greičiau tekantis besikondensuojantis garas pasroviui kaitina ir greitina vandeni prie paviršiaus. Nuo tam tikro pradinio garo greičio priklausančio atstumo iš pradžių laminariškai tekejjusiame vandenyje prasideda turbulencija (pvz., esant pastoviam tiekiamo vandens greičiui $0,014 \mathrm{~m} / \mathrm{s}$ kanale, didinant tiekiamo garo greiti nuo $6 \mathrm{~m} / \mathrm{s}$ iki $12 \mathrm{~m} / \mathrm{s}$, turbulencijos sužadinimo vieta pasislenka nuo $x / h=\sim 28$ iki 9,4 skerspjūvio). Dèl tarpfazinès sąveikos teigiamo grižtamojo ryšio vykstant garo kondensacijai intensyvi turbulencija greitai apima visą vandens skerspjūvị - ívyksta turbulencijos sužadinimas.

4. Turbulencijos sužadinimas priklauso nuo tiekiamo vandens ir garo greičių. Didinant tiekiamo garo greiti ir esant pastoviam vandens greičiui, turbulencijos sužadinimas slenka ì kanalo pradžią. Didinant tiekiamo vandens greitị ir esant pastoviam garo greičiui, turbulencijos sužadinimas slenka ị kanalo pabaigą.

Gauta 20140627

Priimta 20141229

\section{Literatūra}

1. Ruspini L. C., Marcel P. M., Clausse A. Two phase flow instabilities: A review. International Journal of Heat and Mass Transfer. 2014. Vol. 71. P. 521-548.

2. Gada V. H., Datta D., Sharma A. Analytical and numerical study for two phase stratified-flow in a plane channel subjected to different thermal boundary conditions. International Journal of Thermal Sciences. 2013. Vol. 71. P. 88-102.

3. Ghosh S., Pratihar D. K., Maiti B., Das P. K. Automatic classification of vertical counter-current two phase flow by capturing hydrodynamic characteristics through objective descriptions. International Journal of Multiphase Flow. 2013. Vol. 52. P. 102-120.

4. Harris D. C. Durable 3-5 $\mu \mathrm{m}$ transmitting infrared window materials. Infrared Physics \& Technology. 1998. Vol. 39. P. 185-201. 
5. Gupta D., Park Y. G., Jacobi A. M. An experimental study of condensate retention on the air side of flat tube heat exchangers. Proceedings of the 14th International Heat Transfer Conference, 8-13 August 2010, Washington, DC, USA. Vol. 2. Inc. Paper IHTC14-22986. P. 227-234.

6. Celata G. P., Cumo M., Farello G. E., Focardi G. Direct contact condensation of superheated steam on water. International Journal of Heat and Mass Transfer. 1987. Vol. 30. Issue 3. P. 449-458.

7. Lee K., Chu I. C., Yu O. S., No H. C. Interfacial condensation for countercurrent steam-water stratified wavy flow in a horizontal circular pipe. International Journal of Heat and Mass Transfer. 2006. Vol. 49. P. 3121-3129.

8. Gasiūnas S., Šeporaitis M., Čèsna B., Valinčius M., Pabarčius R., Laurinavičius D. Interfacial shear of co-current steam-water flow estimation - II. Enhanced single-phase fluent model in conjunction with measured profiles of steam velocity and longitudinal water temperature. Heat Transfer Research. 2012. Vol. 43. Issue 5. P. 425-442.

Darius Laurinavičius, Marijus Šeporaitis, Stasys Gasiūnas

\section{INVESTIGATION OF HEAT REMOVAL FROM THE INTERFACE AREA TO WATER BULK APPLYING A THERMOGRAPHY METHOD}

\section{Summary}

Condensation is a phenomenon widely studied for many years. However, the experimental data fragmentation and wide application of simplified theoretical models prevent the consolidation and development of the condensation phenomenon model corresponding to the known reality in all aspects. Both the experimental data and the models are obtained and developed in order to meet the practical needs of the industry first and foremost - only the most widely used regimes have attracted researchers' attention. However, because fundamental research is very difficult the objectives were usually limited to the optimization of the processes, and other practical tasks. One of not adequately understood and analysed regime is stratified two-phase flow with surface instability induced by direct phase interaction in the interface.

This paper presents water temperature profiles measured in stratified co-current two-phase flow (steamwater) inside a short and narrow rectangular channel. Measurements were made at $x / h=9.4 ; 14.8 ; 20.4 ; 39.2$ $(166,312,458,932 \mathrm{~mm})$ from the beginning of the channel, using a nonintrusive thermography method. The thermography method allows with high resolution and low data uncertainty $\left( \pm 2{ }^{\circ} \mathrm{C}\right)$ measuring the water temperature right at the channel sidewall. The different flow conditions were created in the channel by changing velocities of flowing phases (water 0.014 , 0.028 and 0.056 , and steam $6,8,10$ and $12 \mathrm{~m} / \mathrm{s}$ ) and supply water temperature $\left(25^{\circ} \mathrm{C}\right)$. It was found that between different regimes the vertical temperature profiles measured from the interface to the bottom of the channel changed not equally and smoothly. In the tested case the water layer can be virtually divided into 4 zones by height where water temperature changes differently. It was also found that because of the 'condensation-turbulence self-induction' the steam flow momentum transfer to water turbulence occurred not only at the interface (depth of $\sim 1 \mathrm{~mm}$ ) but reached much deeper. By increasing the velocity of steam and at a constant rate of water flow the starting points of 'condensation-turbulence self-induction' move closer to the beginning of direct vapour-water contact.

Key words: two phase flow, water temperature profiles, turbulence, thermography 